\title{
Transatlantica
}

Revue d'études américaines. American Studies Journal

1 | 2017

Morphing Bodies: Strategies of Embodiment in

Contemporary US Cultural Practices

\section{An Interview with Phil Klay}

\section{Lucie Jammes}

\section{(2) OpenEdition}

Journals

Electronic version

URL: https://journals.openedition.org/transatlantica/8951

DOI: 10.4000/transatlantica.8951

ISSN: $1765-2766$

Publisher

Association française d'Etudes Américaines (AFEA)

\section{Electronic reference}

Lucie Jammes, "An Interview with Phil Klay", Transatlantica [Online], 1 | 2017, Online since 27 November 2018, connection on 20 May 2021. URL: http://journals.openedition.org/transatlantica/ 8951 ; DOI: https://doi.org/10.4000/transatlantica.8951

This text was automatically generated on 20 May 2021

\section{(c) (i) (9)}

Transatlantica - Revue d'études américaines est mise à disposition selon les termes de la licence Creative Commons Attribution - Pas d'Utilisation Commerciale - Pas de Modification 4.0 International. 


\title{
An Interview with Phil Klay
}

\author{
Lucie Jammes
}

1 Phil Klay is a Marine Corps veteran of the Iraq War and the author of the short story collection Redeployment, which won the 2014 National Book Award for Fiction. A graduate of the Hunter College MFA program, his writing has appeared in the New York Times, Washington Post, Wall Street Journal, and the Brookings Institution's Brookings Essay series. His essays often focus on the problematic experiences of veterans returning home, and on civilian points of view regarding military service. For Redeployment, he has also received the National Book Critics Circle's John Leonard Award (for best first book of any genre), the James Webb Award for fiction from the Marine Corps Heritage Foundation, and the W.Y. Boyd Literary Award for Excellence in Military Fiction from the American Library Association.

\section{Interview}

Lucie Jammes: I would like to begin this interview with a question about your influences and the notion of literary filiation. Critics have often compared Redeployment to Tim O'Brien's The Things They Carried. What authors have been inspirational in the process of laying the groundwork for Redeployment?

Phil Klay: Being a writer is being a part of a conversation that is taking place through novels, stories, poems, and essays. Redeployment emerged not just out of my experience (which doesn't inform too much of the book) or my factual research (which does), but also out of my reactions to the vast accumulation of writing about war, about the human experience of suffering, and about homecoming. In that regard, there are war writers who are very important to me (David Jones, Isaac Babel, J. Glenn Gray, and Anthony Powell come to mind), but I was also deeply influenced by writers who are writing less about war than about community, about pain and its relationship to religion, or about the complex ways we form the world around us through stories. So Joseph Conrad, Shusaku Endo and Amy Hempel have as much to do with the writing of the collection as Celine or Jaroslav Hasek.

LJ: How do you situate Redeployment in the tradition of war writing and its evolution? Modern writers have tried to break free from the constraint of a very codified genre in order 
to reinvent war narratives. Specialist Jean Kaempfer indeed argues that modern war narratives all share the same typical feature: the desire to be atypical. Would you agree with this statement? To what extent would you say your collection is complying with or breaking away from the conventions of the genre?

PK: It isn't just war literature that tries to be atypical, it's literature in general. Why bother to write something that's been written before? There's no tradition of literature that has fully captured the varieties of human experience, whether it's the tradition of war writing or writing about love or writing about family, or work, or whatever. And even if there was a work that perfectly captured a moment in time, history moves forward, new cultural forms emerge, and the literature that is such a rich source of ideas for us nevertheless, no matter how great, fails to meet the current moment in its irreducible specificity. So new stories emerge, and must always emerge.

Naturally, I wanted to break away from some aspects of the genre, or use stories to critique notions of war that seemed to me to be false or outdated. One simple way I tried to do this was to incorporate different varieties of war experience. So though the book starts with a front-line soldier, we quickly get to stories told by Mortuary Affairs Marines, soldiers handling financial services, adjutants, and the like. We see the act of killing as experienced not simply in the pointing of a rifle and the pulling of a trigger, but as the result of a process in which psychological operations play a part, or in which the killing is never observed because it is carried out by a large group of Marines working on crew-served-weapons. And we see soldiers directly confronting common notions about war, such as simple narratives of psychological trauma or narratives about the incommunicability of war.

$\mathrm{LJ}$ : Your collection often highlights the role of modern technology-screens, in particularin the soldiers' lives. In "Unless It's a Sucking Chest Wound," the narrator spends hours in front of his computer screen, watching videos of the war filmed by Gls and keeping track of the soldiers that are killed in action through a constant update of army-related information websites. In "Ten Kliks South," the narrator is unable to "feel" that he has killed someone because his artillery team was too far removed to witness the consequences of their shot. In "Psychological Operations," death is observed through thermic cameras. Do you think modern war technologies have induced new ways of writing about conflicts-marked by distance and indirectness?

PK: Yes and no. I think modern technology does less than we think. Consider our modern worries about the distance between drone operators and their targets. A drone operator sometimes watches their target for weeks or months before pulling the trigger, gathering intelligence and getting to know their target. And then, after killing them, they sometimes wait and watch to see who retrieves the body, who comes to the funeral. Despite the actual physical distance, this is a radically more intimate form of war than, for example, a medieval soldier who loads a rotting cow onto a catapult and then launches it into a besieged town in the hopes that the carcass will spread disease. Novelty frightens us, but new technology is not the problem.

This is why I wrote "Ten Kliks South" about an artillery crew. To call a howitzer "modern technology" is a bit disingenuous. A modern howitzer is much more reliable and powerful than its ancient forbears, but is still just a more sophisticated variant of technology that Joan of Arc would have been familiar with. And yet, with that ancient weapon we have all the same worries about the ways in which even direct 
participants in combat can be insulated from seeing its consequences, as well as the worries about how to apportion moral responsibility, good or bad, for actions taken collectively.

That said, modern means of delivering information, whether it is through videos on YouTube or through thermal imagery of dying insurgents, allow us ever-increasing access to the "facts of the matter" about war, without offering much in the way of moral illumination. I think that proliferation of knowledge coupled with a radically fractured set of cultural meanings for the information constantly being streamed is significant.

LJ: It seems that in most of your stories, the way in which narrators/characters talk about death and violence is marked by euphemisms. Dialogues display a certain reserve and avoid the heart of the matter. In the same fashion, descriptions of dead bodies remain elusive and implicit, often focusing on peripheral objects ("Bodies"). Likewise, the substantial amount of acronyms in "OIF" downplays the perception of war violence by veiling it under what is almost a foreign language. Would you say that this euphemistic style is a way to convey what belongs to the realm of the unsayable?

PK: Part of the problem is that the stories purely of death and violence have no meaning in and of themselves. To catalogue the sensory perceptions and emotional reactions of a soldier in the midst of a combat experience is only to provide you an in-the-moment sense of things, which is very different from getting at the meaning of things, their moral significance, and how they impel the soldier to refashion his sense of the world.

It is easy enough to tell a war story of that sort and provoke an emotional reactionthe narrator of "Bodies" does this cynically-because stories of extreme violence tend toward a kind of trauma kitsch, the deployment of charged imagery that needs no context to function and yet which, in the absence of context, are meaningless beyond the visceral reactions they provoke. For the soldier, the issue of importance is not the moment of violence but the challenge that moment presents for the emotional, social, and spiritual context of their lives. The "Bodies" narrator's experience of dealing with the bodies of the dead is not simply a gross, horrifying experience, but also one that isolates him from fellow soldiers and reduces his sense of himself to a kind of reductive materialism (which, significantly, is not something common in his unit but is specific to him). The isolated incidents which he holds onto from his deployment therefore do not contain the meaning of his experience in and of themselves, but obtain their meaning through the manner in which he acts in relation to them once he comes back home. It's not about what you saw-it's about what you do with it.

Thus, to have an honest conversation about war experience necessitates a certain reserve, a carefulness about allowing the sheer intensity of war experience to overwhelm the much more delicate set of responses which the characters are in the process of negotiating.

LJ: The collection opens on a striking sentence: "We shot dogs." This condensed syntax seems to echo the actual shooting of the dogs in its rhythmic composition. Did you do any specific work regarding the rhythmic structure of your sentences?

PK: I am obsessive about the rhythms of sentences. For example, initially, the opening sentence of "Bodies" was "There was a time I was angry." Then I changed it to: 
"I used to be angry. I'd tell people about the hajji corpse that exploded all over the colonel and watch their eyes as I laughed about it, big stage laughs."

Which wasn't quite right. Too aggressive. So I rewrote it as:

"For a long time I was angry. I wouldn't talk when people asked, or if I did talk, I'd tell them about the rotten hajji corpse that exploded over the colonel."

The rise of the four syllables of "For a long time," ending in two hard stresses, followed by the fall of the four syllables of "I was angry" felt right. But the rest wasn't working. So I changed it a couple times, sometimes writing much longer opening paragraphs, sometimes getting a bit more emotional, or a bit more reserved. Eventually, I got to what I felt was the right set of ideas:

“For a long time I was angry. If people brought up the war, I wouldn't say anything. Or, and this only happened a few times, I'd bring up the wrong thing, like way the bodies looked."

But, except for the first line, the rhythms didn't work. I fiddled with this for a while, coming up with different variants until I had the final version:

"For a long time I was angry. I didn't want to talk about Iraq, so I wouldn't tell anyone I'd been. And if people knew, if they pressed, I'd tell them lies."

I've already discussed why I liked the first sentence. The second sentence is two clauses of ten syllables bridged by the one-syllable word "so". To my ear (though I always hope it's not just my ear, perhaps you can tell me), the hardest stressed syllable is "talk" in the first part and "tell" in the second. That felt right.

Then we have the third sentence. Since the first sentence has one clause and the second has two, naturally this will have three. "And" prepares us to qualify the second sentence (it really functions as a "but," but in a softer way). The following two clauses rise to hard stressed words, each of which anticipates a problem to which the narrator must respond. First, the four syllable "if people knew" sets the ground for a collision of his anger and people's desire to know more, the three-syllable "if they pressed" delays the explanation and escalates the stakes by implying a small amount of aggression on the part of the audience, and the four-syllable "I'd tell them lies" (it must be four syllables, in order to have the right balance to the line) closes it off, ending on the hard-stressed "lies," which I felt was precisely the right word with which to end the paragraph and thought.

So, in short, for many paragraphs (not all, but the important moments), I think the rhythms through obsessively. I don't know whether this ends up making any kind of sense to anyone other than me, but it is part of how I work.

LJ: I would like to pursue with the notion of homecoming. Foundational pieces of war literature, like Homer's Odyssey, depict the return of the hero as a triumphant and glorious moment. Conversely, several short stories in your collection deal with the aftermath of war - like the titular story "Redeployment" with which the collection opens-and reveal the many difficulties of the soldier's return to the United States. How does your writing deconstruct the cliché of the "return of the hero"?

PK: In defense of Homer (who, I suspect, will continue to do quite well regardless of my defense of him), Odysseus' homecoming is a bit more complicated than a simple, triumphant return. He doesn't recognize the shores of his native Ithaca; the people there don't recognize him (with the exception of his loyal dog), and his house has 
been taken over by suitors to his wife, eager to replace him. In order to complete the return home, he needs to turn his home into a bloodbath. That's no one's ideal return.

So I don't see the emphasis on the difficulty of homecoming in Redeployment as such a break from the past. Homecoming is hard in a variety of different ways. Part of this is related to the changed way in which the soldier has learned to physically navigate a combat environment, a way of operating that not only doesn't make sense back home, but causes great problems. Part of it is also the confrontation with the disconnected civilian world, which doesn't operate according to the relatively straightforward rules of the military, and which likes to project all kinds of ideas onto the veteran that never quite match the individual lived experience, and which complicate the veteran's ability to process that experience through dialogue with other people. And part of this is just the delayed moral accounting of war which must happen stateside because when in war, as depicted in "FRAGO," the soldier must focus on the relentless churn of operations so that he or she may be a functional member of the collective.

LJ: It seems difficult to evoke your book in terms of genre. Composed of twelve short stories, each putting forward a different narrator and his own experiences, Redeployment offers a kaleidoscopic view of the Iraq war. What made you choose this composite and fragmentary structure over that of the novel? Would you say that the format of the short story is particularly adapted to war writing?

PK: Part of it was out of a simple desire to explore radically different types of war experience without trying to artificially tie them together through a plot that would somehow connect the pure urban combat of the Second Battle of Fallujah to the development work of a Foreign Service Officer in a Provincial Reconstruction Team. Part of it was a reaction to the notions of authenticity and authoritative accounts of war so common to the culture. A veteran returning from any war is often invited to explain "what it's like," and yet "what it's like" will always be radically different for different people, even if they're operating in a similar environment. So instead of one, authoritative-seeming "this is what the Iraq War was like" story I wanted twelve stories, by twelve narrators who wouldn't agree with each other about the war or what it was like or what it meant. I wanted clashing voices who would offer the reader a space to judge, to argue back, to suspect things might be missing.

$\mathrm{LJ}$ : Is the order in which the stories were laid out significant? Does this order convey meaning that could be a key to understanding the collection in its entirety?

PK: Yes. The order was very deliberate. The first story was the first I started writing, back in 2008, while I was still in the Marine Corps. And the last story was the second story I started writing. I knew where I was beginning, and where I was going, and the shape of the collection is meant to move the reader not through a plot so much as through evolving articulation of core experiences of war and homecoming and storytelling. Thus, the most classic war story comes first, a narrator who is a frontline soldier and details the changes in perception and sense of physical threat the war provoked, and who has difficulty coming home. And then we get another frontline story, but this one by a much more Marine-centered narrator, told with a lot of acronyms and interested much more in leadership and maintaining the functioning of a unit. And next we get a war story as refracted through the narrator, who agrees to take credit for a kill he's not responsible for. And then we get a character who shot 
no one, but instead prepared the bodies of the dead to be sent home. That story also brings up questions of sex and violence that are further explored in a later story, "In Vietnam They Had Whores." The middle of the collection has three longer stories dealing with the war from a broader perspective-the incoherence of policy explored through "Money As a Weapons System" (which is preceded by "OIF," a story that is interested in the way institutions expressed themselves at the level of language), the spiritual dimensions of war as explored through "Prayer in the Furnace," and the complications of storytelling and identity as explored through "Psychological Operations." That thread continues for two more stories, and then the final story begins with an act of collective storytelling, as an artillery unit discusses the degree of responsibility each man has for killing an enemy they fired upon, but never see. And that story ends with a failed search for the dead, which is also a search for the sight of something which the narrator hopes will reveal to him the authentic emotional and moral response he should be having to his participation in a collective act of killing, but which he is unable to feel at a visceral level. However, instead of the Iraqi dead and whatever reactions they might provoke (which of course would not provide what the narrator wants or allow him an earned cognitive rest), we get their displacement by a flag-covered corpse, and the narrator imagining it returning to the States.

LJ: The notion of testimony seems particularly present in your work. Characters try to relate what they have endured ("War Stories"), or what they have done ("Psychological Operations"), but it seems that the recounting of one's experience of war is always a challenge. The narrator of "Bodies" ends up telling a harrowing anecdote to a stranger in a bar, highlighting the general difficulty of finding the appropriate audience when one decides to talk. Do you think war testimonies are at all possible? To what extent do you believe fiction and literary creation can be adequate means of testifying to one's experience?

PK: I think war testimonies are necessary. What is not possible is finding the perfect interlocutor. The conversations need to be entered into with a degree of openness on both sides-a civilian willingness to listen and respond, and a veteran willingness to accept or at least to grapple with responses they dislike.

I think fiction creates a space that is ideal for asking the most risky questions about experience. Protected by its artifice, people with different life experiences can enter into the work on equal footing and engage with whatever resonates most deeply with their understanding of the world. Ideally, they bring to the work something not there inherently, but which the work has made room for.

LJ: I am interested in the possible autobiographical dimension of your work. All the stories are first person narratives, sometimes inducing a feeling that we might be dealing with autobiographical material. Indeed, you were a Marine yourself, deployed in Iraq from January 2007 to February 2008. To what extent did this personal experience influence your writing?

PK: The biggest thing my personal experience did was provide me with a desperate motivation to write these stories well. I came back from Iraq feeling as though the conversation we were having as a country was far too thin, and I wanted to enlarge it somehow. The book, then, was not my attempt to create some exquisite piece of art that would exist in the ether but my attempt to enter into a conversation by introducing new, and hopefully complicating, viewpoints.

of course, it also provided me with a few experiences that inform parts of the book, and it introduced me to people who told me stories that made their way into the book 
in changed form. Also, when I was doing research it tended to make veterans more willing to talk to me.

LJ: I would like to follow with a question about your commitment. Do you feel like your book might be a literary testimony for those who are not able to testify by themselves?

PK: I think everyone, even if in subtle ways, provides testimony. If the book helps them in that, or helps them by expressing something they have felt themselves, then that makes me very glad.

LJ: I would like to conclude this interview with a question about your projects. Since you started your literary career with a war story collection, do you think you will continue writing about war in future literary works? In other words, do you consider yourself as a war writer, or will you pursue other subjects? Are you working on anything specific at the moment?

PK: I'm writing a novel now about the U.S. involvement in Colombia, so I'm not quite done with war, even though I'm writing about it from a very different angle. I don't think I'll only write about war, but it is what currently fascinates and troubles me.

As for whether I'm a war writer, I guess I am. I currently write about war, therefore I am a war writer. In another sense, I hope the writing will be good enough to be broader than just telling the world about war. I don't think of Mauriac as the writer you go to in order to learn about provincial France, or Endo as the writer you go to in order to learn about Christians in Japan, or Dostoevsky as the writer you go to in order to learn about Russian weirdos. Hopefully, my work at its best will offer more than just an alternative method of getting the news.

\section{AUTHOR}

\section{LUCIE JAMMES}

Université Toulouse-Jean Jaurès 